\title{
Neurodegenerative Diseases
}

The International Journal of Translational Research on the Nervous System

Founded 2004 by R.M. Nitsch and C.H. Hock

Editors-in-Chief: R.M. Nitsch (2004-2017), C.H. Hock (2004-2014), L. Rajendran (2014)

\section{Editor-in-Chief}

Paul G. Unschuld - University Hospitals of Geneva, Geneva, Switzerland

\section{Founding Editors}

Christoph Hock - University of Zurich, Zurich, Switzerland

Roger M. Nitsch - University of Zurich, Zurich, Switzerland

\section{Associate Editors}

\section{Molecular Imaging}

Michael Schöll - Sahlgrenska University Hospital, Gothenburg, Sweden

\section{Molecular Mechanisms and Biology}

Magdalini Polymenidou - University of Zurich, Zurich, Switzerland

\section{Single Gene Mutations and Autosomal Dominant Disorders}

Wenzhen Duan - The Johns Hopkins Hospital, Baltimore, MD, USA

Neuroinflammation - Immunology, and Gene Therapy

Janine Reichenbach - University Children's Hospital, Zurich, Switzerland

\section{Statistical Genetics}

Stephan Ripke - Charité University Medicine, Berlin, Germany

\section{Clinical Neuroscience and Biomarkers}

Adam M. Brickman - Columbia University, New York, NY, USA

\section{Preclinical Neuroimaging}

Jan Klohs - Swiss Federal Institute of Technology and University of Zurich, Zurich,

Switzerland

\section{Clinical Neuroimaging and Novel Techniques}

Jun Hua - Johns Hopkins University, Baltimore, MD, USA 


\section{Neuroimaging of the Hippocampus}

Christine Tardif - McGill University, Montreal, QC, Canada

Mathematical and Computational Algorithms for Biomedical Image Analysis Ender Konukoglu - Swiss Federal Institute of Technology, Zurich, Switzerland

\section{Mental Health}

Simone Reppermund - University of New South Wales, Sydney, NSW, Australia

\section{Editorial Board Members}

\section{Neurobiology \\ Molecular Biology}

Konrad Beyreuther - University of Heidelberg, Heidelberg, Germany

\section{Cell Biology}

Michel Goedert - Medical Research Council, Cambridge, UK

Takeshi Iwatsubo - University of Tokyo, Tokyo, Japan

Edward H. Koo - University of California San Diego, La Jolla, CA, USA

Nikolaos K. Robakis - Mount Sinai School of Medicine, New York, NY, USA

Gopal Thinakaran - USF Morsani College of Medicine, Tampa, FL, USA

\section{Animal Models}

Jie Shen - Harvard Medical School, Boston, MA, USA

\section{Structural Biology}

Beka Solomon - Tel Aviv University, Tel Aviv, Israel

\section{Clinical Research}

\section{Genetics}

Alexis Brice - Groupe Hospitalier Pitié-Salpêtrière, Paris, France Lars Lannfelt - University of Uppsala, Uppsala, Sweden

Weidong Le - Jiao Tong University, Shanghai, China

Christine Van Broeckhoven - University of Antwerp, Antwerp, Belgium

\section{Neuropathology}

Bernardino Ghetti - Indiana Alzheimer Disease Center, Indianapolis, IN, USA

Colin Masters - The University of Melbourne, Parkville, VIC, Australia

\section{Imaging}

Arno Villringer - Charité University Medicine, Berlin, Germany

\section{Biological Markers}

Kaj Blennow - University of Gothenburg, Gothenburg, Sweden John H. Growdon - Massachusetts General Hospital, Boston, MA, USA 
Neurodegenerative

Diseases

(Continued)

\section{Therapy}

Steven T. DeKosky - University of Virginia, Charlottesville, VA, USA

\section{Drug Discovery}

\section{Pharmaceuticals}

Avraham Fisher - Israel Institute for Biology Research, Ness Ziona, Israel

Boris Schmidt - Clemens Schöpf-Institute for Organic Chemistry and Biochemistry,

Darmstadt, Germany

Hermona Soreq - The Hebrew University, Jerusalem, Israel

Masatoshi Takeda - Osaka Kawasaki Rehabilitation University, Osaka, Japan 
S. Karger

Medical and Scientific Publishers

Basel $\cdot$ Freiburg $\cdot$ Hartford $•$ Oxford $•$ Bangkok $\cdot$ Dubai $\cdot$ Kuala Lumpur $•$ Melbourne $\cdot$ Mexico City $\cdot$ Moscow $•$ New Delhi $\bullet$ Paris $\bullet$ Shanghai $\cdot$ Tokyo

\section{Disclaimer}

The statements, opinions and data contained in this publication are solely those of the individual authors and contributors and not of the publisher and the editor(s). The appearance of advertisements in the journal is not a warranty, endorsement, or approval of the products or services advertised or of their effectiveness, quality or safety. The publisher and the editor(s) disclaim responsibility for any injury to persons or property resulting from any ideas, methods, instructions or products referred to in the content or advertisements.

Drug Dosage

The authors and the publisher have exerted every effort to en sure that drug selection and dosage set forth in this text are in accord with current recommendations and practice at the time of publication. However, in view of ongoing research, changes in government regulations, and the constant flow of information relating to drug therapy and drug reactions, the reader is urged to check the package insert for each drug for any change in indications and dosage and for added warnings and precautions. This is particularly important when the recommended agent is a new and/or infrequently employed drug.
All rights reserved

No part of this publication may be translated into other languages, reproduced or utilized in any form or by any means, electronic or mechanical, including photocopying, recording, microcopying, or by any information storage and retrieval system, without permission in writing from the publisher or in the case of photocopying, direct payment of a specified fee to the Copyright Clearance Center (see "General Information")

(c) Copyright $2020 / 2021$ by S. Karger AG,

CH-4009 Basel (Switzerland)

Printed on acid-free and non-aging paper (ISO 9706) 


\section{Diseases}

\section{No. 1}

1 Publisher's Note

Research Articles

2 Magnetic Resonance Spectroscopy following Mild Traumatic Brain Injury: A Systematic Review and Meta-Analysis on the Potential to Detect Posttraumatic Neurodegeneration Eisele, A. (Zurich); Hill-Strathy, M. (Zurich/St Andrews); Michels, L. (Zurich); Rauen, K. (Zurich/Schlieren)

12 Analysis of Neuropsychiatric Symptoms in Patients with Alzheimer's Disease Using Quantitative EEG and sLORETA Shim, Y.S. (Seoul); Shin, H.-E. (Bucheon)

20 Ferroptosis Is Regulated by Mitochondria in Neurodegenerative Diseases Zhou, J.; Jin, Y.; Lei, Y.; Liu, T.; Wan, Z.; Meng, H.; Wang, H. (Changchun) Brief Reports

35 First Recognized Patient with Genetic Vitamin E Deficiency Stable after 36 Years of Controlled Supplement Therapy Kohlschütter, A.; Finckh, B.; Nickel, M.; Bley, A. (Hamburg); Hübner, C. (Dresden)

39 Clinical Phenotype of LRRK2 R1441C in 2 Chinese Sisters Lim, S.-Y.; Lim, J.L.; Ahmad-Annuar, A. (Kuala Lumpur); Lohmann, K. (Lubeck); Tan, A.H.; Lim, K.B.; Tay, Y.W. (Kuala Lumpur); Shing, Y.L. (Frankfurt am Main); Muthusamy, K.A. (Kuala Lumpur); Bauer, P.; Rolfs, A. (Rostock); Klein, C. (Lubeck)

46 What Shall We Do for the Patients with Shaky Leg Syndrome? A Review of 23 Patients

Park, S. (Daegu); Lim, J.G.; Chang, H.J.; Oh, E. (Daejeon)

No. 2-3

Review Article

55 Alpha-Synuclein: The Interplay of Pathology, Neuroinflammation, and Environmental Factors in Parkinson's Disease

He, S. (Guilin/Guangzhou); Zhong, S.; Liu, G.; Yang, J. (Guilin)

Research Articles

65 Mutant G2019S-LRRK2 Induces Abnormalities in Arteriolar Cerebral Blood Volume in Mouse Brains: An MRI Study Ning, B.; Guo, G.; Gu, C.; Xu, J.; Bibic, A.; He, X.; Liu, H.; Chen, L.; Wei, Z.; Duan, W.; Liu, P.; Lu, H.; van Zijl, P.C.M.; Ross, C.A.; Smith, W.; Hua, J. (Baltimore, MD)
73 Suppression of NLRP3 Inflammasome, Pyroptosis, and Cell Death by NIM811 in Rotenone-Exposed Cells as an in vitro Model of Parkinson's Disease

Zhang, M. (Yinchuan/Durham, NC/Xian); He, Q. (Durham, NC); Chen, G (Yinchuan); Li, P.A. (Durham, NC)

84 The Expanding Phenotypic Spectrums Associated with ATP1A3 Mutation in a Family with Rapid-Onset Dystonia Parkinsonism

Yuan, Y.; Ran, L.; Lei, L.; Zhu, H.; Zhu, X.; Chen, H. (Changsha)

90 Effects of Virtual Reality with Motor Imagery Techniques in Patients with Parkinson's Disease: Study Protocol for a Randomized Controlled Trial

Kashif, M. (Lahore/Faisalabad); Ahmad, A. (Lahore); Bandpei, M.A.M. (Lahore/Tehran); Gillani, S.A.; Hanif, A. (Lahore); Iram, H. (Faisalabad)

97 Herpesvirus Infections and Risk of Parkinson's Disease Camacho-Soto, A.; Faust, I. (St. Louis, MO); Racette, B.A. (St. Louis, MO/ Parktown); Clifford, D.B. (St. Louis, MO); Checkoway, H. (San Diego, CA); Searles Nielsen, S. (St. Louis, MO)

Brief Reports

104 Effects of Rivastigmine on Patients with Spinocerebellar Ataxia Type 3: A Case Series of Five Patients Grobe-Einsler, M.; Vogt, I.R.; Schaprian, T. (Bonn); Hurlemann, R. (Oldenburg); Klockgether, T.; Kaut, O. (Bonn)

110 Prefrontal Cortex Transcriptomic Deconvolution Implicates Monocyte Infiltration in Parkinson's Disease Batchu, S. (Bethesda, MD)

No. 4

Review Article

113 Postoperative Cognitive Dysfunction and the Protective Effects of Enriched Environment: A Systematic Review Hua, M.; Min, J. (Nanchang)

Research Articles

123 The Added Value of Inflow-Based Vascular-Space-Occupancy and Diffusion-Weighted Imaging in Preoperative Grading of Gliomas

Cao, H.; Xiao, X. (Guangzhou); Hua, J. (Baltimore, MD); Huang, G.; He, W.; Qin, J.; Wu, Y.; Li, X. (Guangzhou)

131 Sleep-Disordered Breathing in Patients with Motor Neurone Disease: One Size Does Not Fit all

Aiyappan, V.; Catcheside, P.; Antic, N.; Keighley-James, G.; Mercer, J.; McEvoy, R.D. (Bedford Park, SA) karger@karger.com

www.karger.com

Karger ${ }^{\prime \prime}$
(C) 2020/2021 S. Karger AG, Basel

Access to full text and tables of contents, including tentative ones for forthcoming issues: www.karger.com/ndd_issues 
139 Association of Progressive Supranuclear Palsy Rating Scale with Progressive Supranuclear Palsy Quality of Life Scale Pantelyat, A. (Baltimore, MD); Higginbotham, L. (Atlanta, GA); Rosenthal, L.; Lanham, D.; Nesspor, V. (Baltimore, MD); AlSalihi, M. (Kansas City, MO); Bang, J.; Wang, J.; Albert, M. (Baltimore, MD)

147 The Prevalence and Management of Saliva Problems in Motor Neuron Disease: A 4-Year Analysis of the Scottish Motor Neuron Disease Register

Pearson, I.; Glasmacher, S.A.; Newton, J.; Beswick, E.; Mehta, A.R.; Davenport, R.; Chandran, S. (Edinburgh); Pal, S. (Edinburgh/Larbert) CARE-MND consortium

153 Brain Atrophy Subtypes and the ATN Classification Scheme in Alzheimer's Disease

Cedres, N.; Ekman, U.; Poulakis, K.; Shams, S.; Cavallin, L.; Muehlboeck, S. Granberg, T.; Wahlund, L.-O.; Ferreira, D. (Stockholm); Westman, E. (Stockholm/London); Alzheimer's Disease Neuroimaging Initiative

\section{No. 5-6}

Research Articles

165 Cerebrospinal Fluid Alzheimer's Biomarkers and Neurofilament Light Profile of Idiopathic Normal Pressure Hydrocephalus in China: A PUMCH Cohort Study

Mao, C.; Sha, L.; Liu, C.; Chu, S.; Li, J.; Huang, X.; Lei, D.; Wang, J.; Dong, L.; Xu, Q.; Peng, B.; Cui, L.-Y.; Gao, J. (Beijing)

173 Diffusion Tensor Imaging Reveals Whole-Brain Microstructural Changes in the P301L Mouse Model of Tauopathy

Massalimova, A.; Ni, R. (Zurich); Nitsch, R.M. (Zurich/Schlieren); Reisert, M.; von Elverfeldt, D. (Freiburg); Klohs, J. (Zurich)
185 Involvement of the Auditory Pathway in Spinocerebellar Ataxia Type 7

Ramos-Languren, L.E. (Mexico City); Rodríguez-Labrada, R.

(Holguin/Havana); Magaña, J.J. (Mexico City); Canales-Ochoa, N.; González-Zaldivar, Y. (Holguin); Velázquez-Pérez, L. (Holguin/Havana); González-Piña, R. (Mexico City)

193 Computerized Simple Reaction Time and Balance in Nondemented Parkinson's Patients

Arroyo-Ferrer, A.; Andreo, J.; Periáñez, J.A.; Ríos-Lago, M.; Lubrini, G.; Herreros-Rodríguez, J. (Madrid); García-Caldentey, J. (Palma de Mallorca); Romero, J.P. (Madrid)

200 Elevated Levels of Homocysteinesulfinic Acid in the Plasma of Patients with Amyotrophic Lateral Sclerosis: A Potential Source of Excitotoxicity?

Lee, A.; Arachchige, B.J.; Henderson, R. (Brisbane, QLD); Aylward, J. (Auchenflower, QLD); McCombe, P.A. (Brisbane, QLD/Auchenflower, QLD)

207 Extending the Spectrum of Nonmotor Symptoms with Olfaction in Premotor Huntington's Disease: A Pilot Study Heim, B.; Valent, D.; Carbone, F.; Spielberger, S.; Krismer, F.; Djamshidian-Tehrani, A.; Seppi, K. (Innsbruck)

212 The Effects of 8-Week Combined Exercise Training on Inflammatory Markers in Women with Multiple Sclerosis Tadayon Zadeh, F. (Tehran); Amini, H. (Qom); Habibi, S. (Isfahan); Shahedi, V. (Parand); Isanejad, A. (Tehran); Akbarpour, M. (Qom)

\section{Acknowledgement to Reviewers}

